\title{
УЛОГАТА НА ПРОБИОТИКОТ „ДИАСТОП ПРОБИО” ВО ПРЕВЕНЦИЈА НА КОЛОНИЗАЦИЈА И ИНФЕКЦИЈА СО CLOSTRIDIUM DIFFICILE KAJ ХОСПИТАЛИЗИРАНИ ПАЦИЕНТИ
}

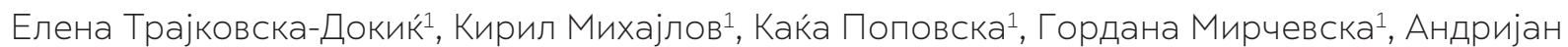 \\ Карталов², Билјана Кузмановска²

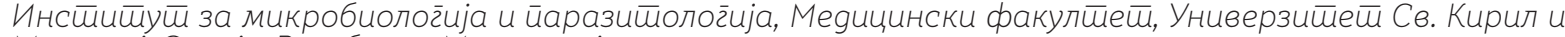

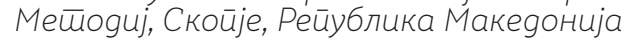

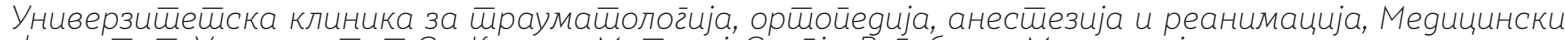

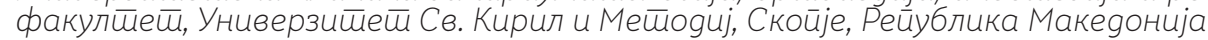

\section{Извадок}

Цитирање: Трајковска-Докиќ Е, Михајлов К Поповска К, Мирчевска Г, Карталов А, Кузмановска Б. Улогата на пробиотикот „Диастоп пробио” clo Clostridim dificilem: "И. Арх ГЗдравје 2018: 10 (1); 12-18

Клучни зборови: Clostridium difficile, пробиотик, хоспитализирани пациенти

*Кореспонденција: проф. д-р Елена Трајковска-Докиќ, Институт за микробиологија и паразитологија, Медицински факултет, Универзитет Св. Кирил и Методиј, Скопје, Република Македонија, E-mail: elenatdokic@gmail.com

Примено: 27-дек-2017;Ревидирано:20-мар-2018 Прифатено: 30-апр-2018; 0бјавено: 30-мај-2018 Печатарски права:` 20182018 Елена Трајковска-Докик.. Оваа статија е со отворен пристап дистрибуирана под условите на нелокализирана лиценца, која овозможува неограничена употреба, дистрибуција и репродукција на било ко медиум, доколку се цитираат оригиналниот(ите) автор(и) и изворот.

Конкурентски интереси: Авторот изјавува дека нема конкурентски интереси

\section{CLINICAL SCIENCE}

Механизмите за адаптација со кои располагаат микроорганизмите од цревниот микробиом го одредуваат нивното квалитативно и квантитативно присуство. Еден од најзначајните фактори кои значајно го нарушуваат цревниот микробиом, овозможувајќи им на условно патогените бактерии да предизвикаат инфекции, е употребата на антибиотиците во терапија на голем број инфекции. Токму таква е инфекцијата која ја предизвикува $C$. difficile. Целта на нашата студија беше да се испита дали пробиотикот „Диастоп пробио” може да ја превенира колонизацијата и инфекција со C. difficile кај хоспитализи рани пациенти. Материјал и методи: Во студијата беа вклучени вкупно 32 пациенти, кои беа третирани истовремено со два од наведените антибиотици: Ceftriaxon, Clindamycin, Ciprofloxacin, Imipenem, Meropenem и Amikacin. Шеснаесет пациенти ја сочинуваа групата на испитаници, кои го примаа и пробиотикот „Диастоп пробио”, а другите 16 пациенти од контролната група не добиваа пробиотик. Од сите пациенти беа добивани по два примерока за детекција на колонизација или инфекција со C. difficile, со класични микробиолошки техники. Истовремено беше проценувана и квалитативната застапеност на нормалната цревна флора. Резултати: Кај пациентите од групата испитаници, процентот на детектираните токсични соеви на $C$. difficile беше 3 пати повисок во однос на пациентите од контролната група $(\mathrm{p}<0,05)$. Истовремено кај пациентите кои примаа пробиотик беше забележан сигнификантно помал процент на дизбаланс во нормалната цревна флора (p<0,05). Кај сите пациенти кои не примаа пробиотик нормалната цревна флора беше редуцирана или потполно отсутна, а 43,75\% од нив беа носители на патогени микроорганизми: P. aeruginosa, VRE, ESBL+ E. coli u Candida albicans. Заклучок: Третирањето на хоспитализираните пациенти со пробиотикот „Диастоп пробио”, како дополнување на нивната антибиотска терапија, придонесува за: значајно намалување на дизбалансот во цревната флора, кој е важен предуслов за колонизација со C. difficile, значајно намалување на фреквенцијата на инфекцијата со C. difficile, што резултира со намален ризик за развивање на некоја од можните живото загрозувачки компликации. Ординирањето на испитуваниот пробиотик истовремено со спроведување на антибиотската терапија кај хоспитализираните пациенти би го спречило населувањето на нивниот дигестивен тракт со значајни микроорганизми, за кои е познато дека предизвикуваат интрахоспитални инфекции.

\section{THE ROLE OF PROBIOTIC "DIASTOP PROBIO” IN PREVENTION OF CLOSTRIDIUM DIFFICILE COLONIZATION AND INFECTION IN HOSPITALIZED PATIENTS}

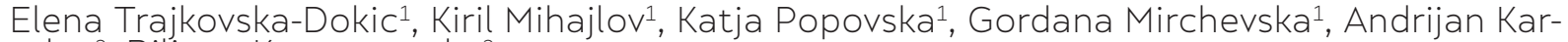
talov², Biljana Kuzmanovska²

Ph1Institute of Microbiology and Parasitology, Medical Faculty, University Sts Ciril and Methodius, Skopje, Republic of Macedonia

University Clinic for traumatic injuries, orthopedics, anesthesia and reanimation, Medical Faculty, University Sts Ciril and Methodius, Skopje, Republic of Macedonia

\section{Abstract}

Citation: Trajkovska-Dokic E, Mihajlov K, Popovska K, Mirchevska G, Kartalov A, Kuzmanovska B. The role of probiotic "Diastop probio" in prevention of Clostridium difficile colonization and infection in hospitalized patients. Arch Pub Health 2018: 10 (1); $12-18$

Key words: Clostridium difficile, probiotic, hospital ized patients

*Correspondence: prof. d-r Elena Trajkovska-Dokic, Institute of Microbiology and Parasitology, Medicl Faculty University Sts Ciril and Methodius, Slopie, Repubic of Macedonia. 5 mail: elenatloSkopje, Republic of Macedonia. E-mail: elenatdokic@gmail.com

Received: 27-Dec-2017; Revised: 20-Mar-2018; Accepted: 30-Apr-2018; Published: 30-May-2018 Copyright:@ 2018. Elena Trajkovska-Dokic. This is an open-access article distributed under the term of the Creative Commons Attribution License which permits unrestricted use, distribution, and reproduction in any medium, provided the original author(s) and source are credited.

Competing Interests: The author have declared that no competing interests

Mechanisms for adaptation of microbes from the intestinal microbiome determine their quantitative and qualitative presence in the intestinal tract. One of the most important disturbing factors of the intestinal microbiome which enable oportunistic bacteria of the gut to reveal their pathogenic properties and cause infections is the antibiotic treatment of infections with different locations. Clostridium difficile infection is a typical example of this kind. The aim of our study was to investigate the possibility of the probiotic "Diastop probio" in preventing colonization and infection of intestine with Clostridium difficile, in hospitalized patients. Material and methods: A total of 32 patients who were treated with any two of the following antibiotics: Ampicillin, Ceftriaxon, Clindamycin, Ciprofloxacin, Imipenem, Meropenem, Amikacin, were included in the study. Sixteen patients represented the respondent group that received the probiotic "Diastop probio" simultaneously with their antibiotic treatment and the other 16 patients represented the control group who were treated with antibiotics only. Two specimens from each patient were obtained for detection of $C$ difficile colonization or infection with classical microbiological methods. Qualitative presence of normal intestinal flora was simultaneously analyzed. Results: The percentage of toxigenic C.difficile strains was three times higher in the respondent group of patients than in the control group of patients $(p<0.05)$. A significantly lower percentage of disbalance in the normal intestinal flora was registered in patients receiving probiotic simultaneously with their antibiotic treatment. In all patients who had not received probiotics, the normal intestinal flora was reduced or completely absent and in $43.57 \%$ of them other pathogenic microorganisms: $P$. aeruginosa, VRE, ESBL+ E. coli and Candida albicans were detected. Conclusions: The treatment of hospitalised patients with probiotic "Diastop probio" simultaneously with their antimicrobial treatment, contributes to: significant decrease of intestinal flora disturbance, as an important prerequisite for colonization of $C$. difficile, significant decrease of the frequency of C.difficile infection, which decreases the risk for development of lifethreatening complications. Treatment of hospitalized patients with the examined probiotic simultaneously with their antimicrobial treatment should prevent gut colonization with microorganisms, known as causes of hospital infections. 


\section{Вовед}

Од средината на дваесеттиот век континуирано се зголемува бројот на животоспасувачките медицински новини. Антимикробните агенси, вакцините, чистата вода за пиење, здравата, сигурна и квалитетна храна, средствата и постапките за дезинфекција и стерилизација, значајно ги подобрија како здравјето на луѓето така и сигурноста на пациентите. Наспроти ова, денес сме сведоци на постојаниот пораст на инциденцијата на инфекциите чии причинители се резистентните бактерии кон голем број антибиотици: метицилин резистентен Staphylococcus aureus (MRSA), ванкомицин резистентен Enterococcus (VRE), Грам-негативни бацили кои лачат бета-лактамази со проширен спектар на делување (ESBL позитивни Грам-негативни бактерии) и карбапенемаза продуцирачки Грам-негативни бактерии. Во последните 5-10 години, кон оваа група на резистентни бактерии се приклучува и Clostridium difficile (C. difficile)., ${ }^{1,2}$

C. difficile е анаеробна, спорогена, Грам-позитивна, стапчеста бактерија. Најчесто, таа го наоѓa својот резервоар во дигестивниот тракт на колонизираните и инфицираните пациенти во болниците и во институциите каде тие престојуваат долго време (старските домови), на контаминираните површини во нивната околина, на контаминираната медицинска и немедицинска опрема, но исто така и во околината вон болниците: во земјата, дигестивниот тракт на животните и во храната. Заради терморезистенцијата, резистенцијата на исушување и на низа дезинфициенси, спорите на $C$. difficile долго време преживуваат во болничка средина и лесно се пренесуваат по феко-орален пат, навлегувајќи во дигестивниот тракт на пациентите. ${ }^{3}$ Се смета дека од 2\% до 4\% од здравите индивидуи и од 10\% до 15\% од хоспитализираните пациенти се колонизирани со C. difficile, којшто претставува дел од цревниот микробиом. Механизмите за адаптација со кои располагаат микроорганизмите од цревниот микробиом го одредуваат нивното квалитативно и квантитативно присуство во дигестивниот тракт. Меѓутоа, цревниот микробиом е секојдневно изложен на многубројни промени, како од ендогено така и од егзогено потекло. Еден од најзначајните фактори кои значано го нарушуваат цревниот ми- кробиом овозможувајќи им на условно патогените бактерии да предизвикаат инфекции е употребата на антибиотиците во терапија на голем број инфекции. Токму таква е инфекцијата која ја предизвикува $C$. difficile. ${ }^{4}$ По навлегување на спорите на $C$. difficile во дигестивниот тракт, тие герминираат; вегетативните форми пролиферираат и ги излачуваат своите токсини, директно оштетувајќи ја слузницата на дебелото црево и предизвикувајќи антибиотски-асоциран колитис, псевдомембранозен колитис и токсичен мегаколон. ${ }^{5}$ Ова особено често се случува кај пациенти кои биле изложени на долготрајно дејство на антибиотска терапија со следните антибиотици: Clindamycin, Ampicillin, Amoxicillin, Cephalosporin (III, IV), Fluoroquinolone. Други ризик-фактори за развиток на инфекција со $C$. difficile (CDI) се: напредната возраст (над 65 години), други коморбидитети, имуносупресија, хемотерапија. ${ }^{6}$

Многу извештаи укажуваат дека хоспитализираните пациенти со CDI бараат дополнителен медицински третман уште 1 до 3 недели. Тоа значи дополнително зголемување на трошоците за 3000-5000 евра за еден пациент во Велика Британија, а за 1 билион долари годишно во САД. Заради постојаното зголемување на процентот на старото население во Европа, како и заради фактот што CDI се развива најчесто кај возрасните пациенти, за очекување е овие трошоци во иднина значително да пораснат, а со тоа дополнително да го оптоварат здравствениот буџет. Во прилог на ова говорат последните податоци од Eurostat (статистичко биро во Европската Унија), според кои бројот на индивидуите над 65 години во Европа до 2050 година ќе се дуплира и од 75,3 милиони во 2010, тој број ќе се искачи на 134,5 милиони. ${ }^{8}$

Според истражувањата кои се спроведени од страна на Европскиот центар за контрола и превенција на заболувањата (ECDC) во периодот 2013-2014 година, а кои се однесуваат на преваленцијата на инфекциите кои се стекнуваат во болниците и употребата на антибиотиците во болниците низ Европа, со 5,4\% C. difficile е на 7-то место на листата на микроорганизмите кои предизвикуваат болнички инфекции. ${ }^{9,10}$ Во споредба со резултатите добиени од истиот вид на истражување спроведено пред само четири години, се забележува дека преваленцијата на CDI 
низ европските болници пораснала скоpo 3 пати. Според едно наше испитување направено во текот на 2015 година на пациенти кои беа хоспитализирани на 4 интерни и 4 хируршки клиники при клиничкиот кампус „Мајка Тереза” во Скопје, 12,3\% од пациентите биле колонизирани, a 8,4\% од пациентите биле инфицирани co C. difficile. Земајќи го предвид главниот фактор кој доведува до развиток на CDI (употреба на антибиотици кои предизвикуваат дизбаланс во цревниот микробиом), се наметнува идејата за употреба на корисните бактерии за човековиот организам т.е. пробиотиците за превенирање на гастроинтестиналните нарушувања и компликациите од нив, како што е CDI. Тајната на успехот на пробиотиците како заштита против патогените микроорганизми се нивните антибактериски ефекти. ${ }^{11}$ Ефикасниот пробиотик поседува доволен број бактерии кои ги преживуваат дигестивните процеси, ги колонизираат цревата и предизвикуваат корисен локален и системски одговор кај домаќинот.

Целта на нашата студија беше да се испита дали пробиотикот „Диастоп пробио” може да ја превенира колонизацијата и инфекцијата на цревата со C. difficile кај хоспитализирани пациенти на две клиники при Клиничкиот центар „Мајка Тереза” во Скопје.

\section{Материјал и методи}

Во студијата беа вклучени вкупно 32 пациенти, хоспитализирани на одделите за интензивно лекување при Универзитетската клиниката за неврохирургија и при Универзитетската клиниката за трауматологија, ортопедија, анестезија и реанимација (ТОАРИЛ). Сите пациенти беа оперирани заради некоја од следните дијагнози: Polytraumatismus, Contusio cerebri, Haemorrhagio intraventricularis, Haemathoma subdurale, Tu cerebri. Boзраста на пациентите се движеше помеѓу 51 и 72 години. Групата на испитаници ја сочинуваа 16 пациенти, кои 24 часа пред операцијата и во тек на постоперативниот период, покрај третманот со два од наведените антибиотици (Ceftriaxon, Clindamycin, Ciprofloxacin, Imipenem, Meropenem, Amikacin), добиваа и пробиотик „Диастоп пробио”, кој содржи четири вида млечнокиселин- ски бактерии: Lactobacillus acidophilus, Streptococcus thermophilus, Bifidobacterium BB и Lactobacillus delbrueckii. Шеснаесет пациенти од контролната група во текот на антибиотската терапија не добиваа пробиотик. Од сите 32 пациенти беа добиени по два фекални примерока. Првите примероци беа добивани помеѓу првиот и третиот ден од приемот на пациентите на соодветниот оддел, а вторите примероци беа добивани 7 до 10 дена подоцна.

Лабораториската дијагноза на инфекцијата со C. difficile беше заснована на алгоритам составен од два брзи имуноензимски теста. ${ }^{12}$ Најнапред, со ензимот глутамат дехидрогеназа беше детектирано присуството на $C$. difficile директно во фекалниот примерок, а потоа со идентификација на токсините А/Б беа диференцирани токсичните соеви на $C$. difficile. Истовремено, фекалните примероци беа засадувани на крвен и Шедлер агар и инкубирани во аеробни и анаеробни услови, соодветно. На овој начин квалитативно беше проценувано присуството, редукцијата или потполното отсуство на нормалната цревна флора кај пациентите.

\section{Резултати}

Кај двајца (12,5\%) од вкупно 16 пациенти од групата испитаници, беше детектиран токсичен сој на $C$. difficile, при што едниот сој беше детектиран во двата примерока, а другиот сој беше детектиран само во првиот фекален примерок (табела 1). Кај 1 пациент од истата група беше детектиран нетоксичен сој на $C$. difficile само во првиот фекален примерок. Кај овие 3 пациенти како и кај уште двајца од истата група, нормалната цревна флора беше редуцирана само во првите примероци. Во примероците од останатите 11 пациенти од оваа група, во кои не беше детектиран C. difficile, нормалната цревна флора беше присутна во двата примерока (табела 1). Според ова, кај 12,5\% од пациентите кои примаа пробиотик беше докажана инфекција со C. difficile, а 6,25\% од нив беа колонизирани со оваа бактерија. Нормалната цревна флора беше редуцирана кај 31,25\% од првите примероци, додека пак во вторите примероци таа беше редуцирана само кај еден пациент, односно беше нормална кај 93,75\% од пациентите (табела 1). 
Табела 1. C. difficile инфекција/колонизација и цревна микрофлора кај пациенти кои не примале пробиотик

\begin{tabular}{|c|c|c|c|c|c|c|c|c|c|}
\hline \multirow{2}{*}{$\begin{array}{c}\text { Реден } \\
\text { бројна } \\
\text { примерок }\end{array}$} & \multicolumn{2}{|c|}{ C. difficile } & \multicolumn{4}{|c|}{ Цревна флора } & \multirow{2}{*}{\multicolumn{2}{|c|}{$\begin{array}{c}\text { c. difficile } \\
\text { инфекција }\end{array}$}} & \multirow{2}{*}{$\begin{array}{c}\text { C. difficile } \\
\text { колонизација }\end{array}$} \\
\hline & GDH & А/В токсин & \multicolumn{2}{|c|}{ Редуцирана } & \multicolumn{2}{|c|}{ Нормална } & & & \\
\hline \multirow{6}{*}{ I } & + & + & + & \multirow{5}{*}{$31,25 \%$} & \multicolumn{2}{|c|}{-} & + & \multirow{2}{*}{$12,5 \%$} & - \\
\hline & + & + & + & & \multicolumn{2}{|c|}{ - } & + & & - \\
\hline & + & - & + & & \multicolumn{2}{|c|}{ - } & \multicolumn{2}{|r|}{ - } & $+6,25 \%$ \\
\hline & - & - & + & & \multicolumn{2}{|c|}{ - } & \multicolumn{2}{|r|}{ - } & - \\
\hline & _- & - & + & & \multicolumn{2}{|c|}{-} & \multicolumn{2}{|r|}{ - } & - \\
\hline & - & - & \multicolumn{2}{|r|}{ - } & \multicolumn{2}{|c|}{$\begin{array}{c}(+) \\
11 / 16(68,75 \%)\end{array}$} & & - & - \\
\hline \multirow{3}{*}{ II } & + & + & + & $6,25 \%$ & - & - & + & $6,25 \%$ & - \\
\hline & - & - & & - & $\begin{array}{l}+(+) 11 / 16 \\
(68,75 \%)\end{array}$ & \multirow[t]{2}{*}{$93,75 \%$} & \multirow{2}{*}{\multicolumn{2}{|c|}{-}} & \multirow{2}{*}{-} \\
\hline & - & - & & - & $\begin{array}{l}(+) 4 / 16 \\
(25,0 \%)\end{array}$ & & & & \\
\hline
\end{tabular}

Четири од шесте $(66,6 \%)$ пациенти кои примаа пробиотик, кај кои воедно беше детектирано редуцирано присуство на нормалната цревна флора, беа третирани со клиндамицин и цефалоспорин од III генерација, а 2/6 (33,3\%) од нив примаа карбапенем со флуорокинолон. Кај останатите 10 пациенти од оваа група нормалната цревна флора беше присутна и покрај нивниот третман со следните комбинации на антибиотици: ванкомицин со флуорокинолон, ванкомицин со карбапенем и флуорокинолон со карбапенем.
Кај вкупно 6 пациенти (37,5\%) од контролната група беше детектиран токсичен сој на C. difficile. Кај четворица $(25,0 \%)$ од тие 6 пациенти, токсичен сој на C. difficile беше детектиран во двата примерока, а кај двајца (12,5\%) токсичен сој на C. difficile беше детектиран само во вторите фекални примероци. C. difficile не беше детектиран кај 12/16 (75,0\%) и кај 10/16 (62,5\%) од првите и вторите примероци, соодветно. Кај сите 16 пациенти од контролната група нормалната цревна флора беше редуцирана до комплетно отсутна (табела 2).

Табела 2. C. difficile инфекција/колонизација и цревна микрофлора кај пациенти кои примале пробиотик

\begin{tabular}{|c|c|c|c|c|c|c|c|}
\hline \multirow{2}{*}{$\begin{array}{c}\text { Реден } \\
\text { број на } \\
\text { примерок }\end{array}$} & \multicolumn{2}{|c|}{ C. difficile } & \multicolumn{3}{|c|}{ Цревна флора } & \multirow{2}{*}{\multicolumn{2}{|c|}{$\begin{array}{c}\text { C. difficile } \\
\text { инффекщија }\end{array}$}} \\
\hline & GDH & А/В токсин & & $\begin{array}{l}\text { щирана/ } \\
\text { сутна }\end{array}$ & Нормална & & \\
\hline \multirow{5}{*}{ I } & + & + & + & \multirow{4}{*}{$25,0 \%$} & - & + & \multirow{4}{*}{$25,0 \%$} \\
\hline & + & + & + & & - & + & \\
\hline & + & + & + & & - & + & \\
\hline & + & + & + & & - & + & \\
\hline & - & - & & $\begin{array}{l}(+) \\
(75,0 \%)\end{array}$ & - & & \\
\hline \multirow{7}{*}{ II } & + & + & + & \multirow{4}{*}{$6,25 \%$} & - & + & \multirow{5}{*}{$37,5 \%$} \\
\hline & + & + & + & & - & + & \\
\hline & + & + & + & & - & + & \\
\hline & + & + & + & & - & + & \\
\hline & + & + & + & \multirow{2}{*}{$12,5 \%$} & - & + & \\
\hline & + & + & + & & - & + & \\
\hline & - & - & & $\begin{array}{l}(+) \\
(62,5 \%)\end{array}$ & - & - & - \\
\hline
\end{tabular}


Дванаесет од 16 пациенти (75,0\%) кои не примаа пробиотик, а кај кои истовремено беше детектирано редуцирано присуство или потполно отсуство на нормалната цревна флора, беа третирани со клиндамицин и цефалоспорин од III генерација. Шест од овие дванаесет пациенти беа инфицирани со C. difficile. Еден од 16-те пациенти (6,25\%) кои не примаа пробиотик и истовремено имаа дизбаланс во нивната цревна флора, примаа карбапенем со флуорокинолон, а останатите $3 / 16(18,75 \%)$ пациенти од истата група беа третирани со цефалос- порин од III генерација и флуорокинолон.

Истовремено, во 7 од 16 (43,75\%) примероци добиени од пациентите од контролната група, беа изолирани неколку различни видови резистентни бактерии. Имено, кај 2 пациенти беше изолиран ванкомицин резистентен Enterococcus (VRE), кај 1 пациент беа изолирани истовремено VRE и Pseudomonas aeruginosa, кај 2 пациенти беше изолирана ЕСБЛ + Escherichia coli, а кај 2 пациенти беше изолирана Candida albicans (табела 3).

Табела 3. Изолирани бактерии кај пациентите кои не примале пробиотик и имале дизбаланс во нормалната цревна флора

\begin{tabular}{|c|c|c|}
\hline \multirow[t]{2}{*}{ Патогени микроорганизми } & Редуцирана цревна флора & Отсутна цревна флора \\
\hline & \multicolumn{2}{|c|}{$7 / 16(43,75 \%)$} \\
\hline VR Enterococcus & + & \\
\hline VR Enterococcus & + & \\
\hline $\begin{array}{l}\text { VR Enterococcus } \\
\text { P. aeruginosa }\end{array}$ & + & \\
\hline$E S B L+E$. coli & & + \\
\hline$E S B L+E$. coli & & + \\
\hline C. albicans & & + \\
\hline C. albicans & & + \\
\hline
\end{tabular}

\section{Дискусија}

Улогата на пробиотиците во превенција на колонизација или инфекција co C. difficile cè уште е недоволно испитана. Засега, литературата бележи контрадикторни податоци по ова прашање. ${ }^{13,14,15}$ Според статистичката анализа на добиените резултати, докажана е сигнификантна разлика во застапеноста на токсичните соеви на $C$. difficile помеѓу групата испитаници и контролната група (p<0,05). Имено, кај пациентите од контролната група (кои не примаа пробиотик), процентот на детектираните токсични соеви на $C$. difficile беше 3 пати повисок во однос на пациентите од групата испитаници, кои освен антибиотици примаа и пробиотик (37,5\% : 12,5\%). Кај пациентите кои примаа пробиотик беше детектиран сигнификантно помал процент на дизбаланс во нормалната цревна флора $(p<0,05)$. Кај сите пациенти кои не примаа пробиотик, нормалната цревна флора беше редуцирана или потполно отсутна. При антибиотскиот третман на пациентите од двете групи со комбинација од третогенерациски цефалоспорин и клиндамицин беше забележана сигнификантна поврзаност со дизбалансот на цревната флора и со појава на инфекција со C. difficile, што се совпаѓa со поголем број од податоците во литературата. ${ }^{16}$ Користењето на критериумите за диференцијација на инфекција со C. difficile според местото и времето на нејзиното појавување, ${ }^{17}$ би помогнале во откривање на видот на C. difficile инфекцијата. Детекцијата на токсичните соеви на $C$. difficile во двата фекални примерока кај пациентите од групата испитаници, како и детекцијата на нетоксичниот сој на C. difficile само во првиот фекален примерок, упатува 
на колонизирање/инфицирање на пациентите co C. difficile пред да бидат примени на соодветните клиники. Детекцијата на токсични соеви на $C$. difficile кај 12,5\% од пациентите од контролната група само во вторите фекални примероци укажува дека тие најверојатно ја стекнале инфекцијата за време на нивниот престој на клиниката каде биле хоспитализирани. Останатите 25\% од пациентите во контролната група најверојатно биле инфицирани пред да бидат хоспитализирани на соодветната клиника, затоа што кај нив оваа бактерија беше детектирана помеѓу 1-от и 3-от ден од нивниот прием на соодветната клиника.

Загрижувачки е податокот за присуството на неколку патогени микроорганизми во дигестивниот тракт на 43,75\% од пациентите од контролната група. Имено, кај речиси половина од пациентите кои не примаа пробиотик беа детектирани VRE, P. aeruginosa, ESBL+ E. coli и Candida albicans. Овој наод е во прилог на сознанијата за компетитивната улога на пробиотиците во одржување на нормалната цревна флора во текот на антибиотската терапија..$^{18,19}$ Недостатокот на пробиотикот во услови на антибиотска терапија, го олеснува цревниот дизбаланс и со тоа придонесува тие пациенти да станат резервоари на овие резистентни бактерии кои во последно време сѐ почесто предизвикуваат интрахоспитални инфекции.

\section{Заклучок}

Појавата на дизбаланс во цревната микрофлора и развитокот на инфекција со C. difficile корелира со комбиниран антибиотски третман со третогенерациски цефалоспорини и клиндамицин.

Ординирањето на пробиотикот „Диастоп пробио” во текот на антибиотската терапија кај хоспитализираните пациенти: значајно го намали процентот на пациентите со дизбаланс во цревната флора, кој е важен предуслов за стекнување на инфекција со C. Difficile. Исто така значајно го намали процентот на инфицираните пациенти со C. difficile, како предуслов за развиток на одредена компликација од животозагрозувачко значење (псевдомембранозен колитис, токсичен мегаколон, перфорација на дебелото црево).

Освен спречување на колонизација/инфекција со C. difficile, ординирањето на испитуваниот пробиотик како додаток на антибиотскиот третман кај хоспитализираните пациенти, би довело до спречување на населувањето на нивниот дигестивен тракт со значајни микроорганизми, за кои е познато дека предизвикуваат интрахоспитални инфекции, а со тоа би се намалиле морбидитетот и морталитетот кај хоспитализираните пациенти.

\section{Референци:}

1. Vouga M, Greub G. Emerging bacterial pathogens: the past and beyond. Clin Microbiol Infect 2016; 22:12-21.

2. U.S. Department of health and human services, Center for disease control and prevention: Antibiotic resistance treats in the United States, 2013.

3. Barbut F, Petit J-C. Epidemiology of Clostridium difficile-associated infections. Clin Microbiol Infect 2001; 7:405-10.

4. Beaugerie L, Flahault A, Barbut F, et al. Antibiotic-associated diarrhoea and Clostridioum difficile in the community. Aliment Pharmacol Ther 2003; 17:905-12.

5. Kelly CP, Pothoulakis C, LaMont JT. Clostridium difficile colitis. N Engl J Med 1994; 330:257-62.

6. Kuijper EJ, Coignard B, Tull P. Emergence of Clostridium difficileassociated disease in North America and Europe. Clin Microbiol Infect 2006; 12:2-18.

7. Lessa et al. Burden of Clostridium difficile infection in the United States. N Engl J Med 2015; 372:825-34.

8. Bauer MP, et al. Clostridium difficile infection in Europe: a hospital based survey. Lancet 2011; 377:63-73.

9. Vaishnavi C. Established and potential risk factors for Clostridium difficile infection. Indian J Med Microbiol 2009; 27:289-300.

10. Point Prevalence Survey of Hospital 
acquired infections and antibiotic use in European hospitals; ECDC: 2014.

11. Silva M, Jacobus NV, etal. Antimicrobial substance from a human Lactobacillus strain. Antimicrob Agents Chemother 1987; 31:121-128.

12. Crobach MJ, Dekkers OM, Wilcox $\mathrm{MH}$, Kuijper EJ. European Society of Clinical Microbiology and Infectious Diseases (ESCMID): data review and recommendations for diagnosing Clostridium difficile infection (CDI). Clin Microbiol Infect 2009; 15:1053-66.

13. Wilcox MH, Sandoe JA. Probiotics and diarrhoea: data are not widely applicable. BMJ 2007; 335:171.

14. Thomas MR, Litin SC, et al. Lack of effect of Lactobacillus GG on antibiotic-associated diarrhoea: a randomized, placebo-controlled trial. Mayo Clin Proc 2001; 76:883-889.

15. Wenus C, Goll R, et al. Prevention of antibiotic-associated diarrhoea by a fermented probiotic milk drink. Eur J Clin Nutr 2007; (Epub ahead of print, 14 March 2007).

16. Hoegenauer C, Hammer H. F, et al. Meshanisms and management of antibiotic-associated diarrhoea. Clin Infect Dis 1998; 27:702-10.

17. Cohen SH, Gerding DN, et al. Clinical practice guidelines for Clostridium difficile infection in adults: 2010 update by the society for healthcare epidemiology of America (SHEA) and the infectious diseases society (IDSA). Infect Cont Hosp Epidemiol 2010; 31:431-55.

18. Gorbach SL. Probiotics in gastrointestinal health. Am J Gastroenterol 2000; 95: S2-4.

19. McFarland LV. Evidence-based review of probiotics for antibiotic-associated diarrhoea and Clostridium difficile infections. Anaerobe 2009; 15:274-80. 